\title{
ARTIGO
}

\section{A ONU tem autoridade? Um exercício de contabilidade política (1945-2006)}

\author{
Does the UN have any authority? \\ An exercise of political accountancy (1945-2006)
}

DAWISSON BELÉM LOPES

Rev. Bras. Polít. Int. 50 (1): 47-65 [2007]

\section{Introdução conceitual}

Para tentar responder à questão que motiva esta nossa incursão - qual seja, "A ONU tem autoridade?" -, convém, antes, esclarecer-lhe os termos. Por autoridade, pretende-se aqui a relação bipolar entre o autorizado e o autorizador. Por se tratar de uma relação, e não de uma entidade, a autoridade é imaterial e fluida; embora possa se institucionalizar, essa relação [de autoridade] precede, ontologicamente, a versão reificada - reconhecida, por exemplo, na construção do Estado moderno. A autoridade à qual nos reportamos se constitui entre os elementos que compõem a relação; e não por vínculos sustentados externamente, por via de coerção ${ }^{1}$.

$\mathrm{Na}$ Modernidade, a autoridade veio a ser concebida como a dinâmica da autorização entre seres morais e autônomos, capazes de processar juízos de valor. Diferentemente, portanto, de sua acepção original. A auctoritas, significante latino para uma modalidade de relacionamento já presente entre os gregos, aludia ao processo por meio do qual os deuses dotavam de "autoridade" (esta entendida como "bons auspícios") os humanos bem-aventurados.

Auctoritas deriva do verbo augere (aumentar, ampliar). Aquilo que a auctoritas - ou os que dela se apossam - aumenta é o fundamento valorativo, isto é, a base normativa em que se funda a relação de autoridade. Para compreender

\footnotetext{
Professor de Relaçōes Internacionais do Centro Universitário de Belo Horizonte - UNI-BH, é mestre em Ciência Política pela Universidade Federal de Minas Gerais - UFMG e doutorando em Ciência Política pelo Instituto Universitário de Pesquisa do Rio de Janeiro - Iuperj (dawisson@gmail.com).

1 Uma versão preliminar (e algo distinta) deste trabalho foi apresentada no "XXX Encontro Anual da ANPOCS" (Caxambu-MG, 27 de outubro de 2006), ao Grupo de Trabalho "Ordem Hegemônica, Multilateralismo e Política Externa", sob o título de "A ONU Tem Autoridade? Reflexōes sobre Autoridade, Política e Autoridade Política". O autor agradece imensamente os comentários feitos, à ocasião, pelos professores Alcides Costa Vaz e Rafael Villa, dos quais esta versão final certamente se beneficia. Como de praxe, o autor assume inteira responsabilidade por todas as carências e limitaçôes que o artigo, porventura, conserve.
} 
mais concretamente o que significa "gozar de autoridade", vale observar que a palavra auctores (ou seja, depositários da auctoritas) pode ser utilizada como o antônimo de artifices (os construtores e elaboradores efetivos). Auctor quer dizer o mesmo que "autor". Porém, o autor não é aqui o construtor, mas, sim, "aquele que inspirou toda a empresa e cujo espírito, portanto, muito mais do que o do efetivo construtor, acha-se representado na própria construção". ${ }^{2}$ Distintamente do artifex, que simplesmente fez, o auctor é o verdadeiro genitor do edifício, "autorizado" com um sopro de inspiração pelas divindades.

$\mathrm{Na}$ Roma antiga, o poder coercivo da fundação política era, ele mesmo, de natureza religiosa. A força da autoridade estava intimamente ligada à força religiosa dos auspices, que, ao contrário do oráculo grego, não sugere o curso objetivo dos eventos futuros, mas apenas revela a aprovação ou a desaprovação divina das decisões feitas pelo homem. Os auspices definem se as ações humanas estão ou não devidamente autorizadas pelos deuses. Eles, os deuses, as "aumentam" e as autenticam, mas não as guiam. Na mitologia romana, todos os auspices remontam ao grande sinal pelo qual os deuses deram a Rômulo a autoridade para fundar a sua cidade. Assim sendo, toda autoridade derivaria daquele ato de fundação, remetendo ao sagrado início da história romana e somando, por assim dizer, a cada novo momento singular, o peso do passado. ${ }^{3}$

A autoridade, derivação da auctoritas romana, requer o "pensar mitológico" para ser devidamente apreendida. Não existe, per se, a autoridade do "ocupante do cargo" [office-holder]. Em última análise, quando se faz popularmente referência a uma "autoridade" (pretendendo-se, então, a pessoa que ocupa uma posição institucionalizada de poder), está subsumida a relação prévia de autoridade entre as partes - o que é autorizado e o que autoriza -, relação esta que é mediada por uma forma de simbolismo - o arranjo institucional. A incapacidade de se identificar tal carga simbólica nas relaçôes contemporâneas de autoridade tem acarretado, não raramente, perigosos equívocos para o estudo e a prática da política. $\mathrm{O}$ maior deles, talvez, seja a confusão entre a autoridade (propriamente dita) e o que se convencionou chamar de "exercício da autoridade". É a equivalente moderna da distinção semântica romana entre o auctor e o artifex. Não se quer propor aqui uma relação platônica entre um e outro, entre a idéia e a prática. Antes, parece-nos fundamental, ao estudioso ou interessado em entender a temática, a capacidade de apartar conceitualmente o joio do trigo.

\section{Nota metodológica: como conceber a autoridade política da ONU}

Há pelo menos duas maneiras de pensar a autoridade onusiana. Uma, mais tendente às elaborações "clássicas" da Política, avalia a autoridade da ONU por

2 ARENDT, H. “Que é a Autoridade?”, Entre o Passado e o Futuro. São Paulo: Perspectiva, 1988, p. 164.

3 Id., p. 165. 
via da atuação de seu pessoal autônomo - nomeadamente, o Secretariado e a alta burocracia do sistema ONU. Afere-se a autoridade da ONU, nesse caso, conferindo-se a capacidade que esses homens (não constrangidos, pelo menos em tese, por um mandamento de lealdade a um Estado nacional) demonstram de inspirar confiança em indivíduos e Estados-membros, por meio de suas idéias e ações, gerando, por conseguinte, permeabilidade normativa às diretivas da organização.

Em uma segunda formulação, a ONU pode ser, ela própria, concebida como um "sistema de autoridade". Por esse prisma - nitidamente mais "moderno" -, a Organização das Nações Unidas corresponderia à materialização de princípios e normas tidos como autoritativos por indivíduos e Estados nas relaçóes internacionais contemporâneas (e.g., o multilateralismo e o direito internacional). Essa perspectiva transforma a ONU em veículo da política internacional, capaz de acomodar um determinado conteúdo - extraindo justamente daí a sua "autorização" como ator político (auctor).

A hipótese que norteia o trabalho é de que a Organização das Nações Unidas, ao contrário do que alimenta o senso comum, é uma organização internacional dotada de considerável grau de autoridade política no contexto das relações internacionais contemporâneas, e que o quantum dessa autoridade da qual está investida a ONU é crescente desde a sua fundação, em 1945.

Há problemas evidentes na metodologia positivista que recorre às correlações entre variáveis para explicar certos fenômenos das relaçóes internacionais. Por se tratar de processos sociais - envolvendo seres humanos -, as pretensas relações entre variáveis de causa e de efeito não costumam dar-se unidirecionalmente. $\mathrm{O}$ que se quer afirmar é que, para o caso da autoridade da ONU, dificilmente se poderá dizer, taxativamente, que um percebido aumento dos níveis de confiança que indivíduos ou Estados depositam na ONU induz ao incremento da autoridade da organização; e vice-versa. Até porque, vale frisar, não existe uma unidade conveniente para a mensuração "objetiva" do quantum de autoridade política de que desfrute uma entidade qualquer. Não obstante, queremos postular aqui a plausibilidade de uma relação de afinidade e de alimentação recíproca entre a "autoridade onusiana" e os elementos que serão, na seqüência, submetidos à apreciação do leitor. Mediante a apresentação desses dados, pretendemos corroborar nossa hipótese de trabalho acerca da natureza da autoridade da ONU na política internacional contemporânea.

\section{Propósitos primários e legitimidade}

Se a Organização das Nações Unidas - a sucessora da Liga das Nações - é julgada em relação aos propósitos primários para os quais se constituiu, percebemos desde logo maior adequação entre meios empregados e fins pretendidos. "Quando a ONU foi estabelecida, no imediato pós-Segunda Guerra Mundial, 
o seu objetivo era, acima de tudo, a manutenção da paz" - expõem Roberts e Kingsbury. ${ }^{4}$ No preâmbulo da Carta de São Francisco, encontram-se os dizeres: "Nós, os povos das Naçōes Unidas, determinados a salvar as gerações vindouras do flagelo da guerra, que por duas vezes em nossa existência trouxeram sofrimento indizível à humanidade”. A manutenção da paz, nesses termos, significava impedir a ocorrência de uma terceira guerra em que estivessem envolvidas as grandes potências mundiais - e não, como algumas análises querem fazer crer, impedir qualquer novo confronto internacional. ${ }^{5}$ A suposição jacente era de que, com a criaçáo da ONU - e a concessão do direito de veto aos Cinco Grandes no Conselho de Segurança (EUA, Reino Unido, França, China e União Soviética) -, seriam diminuídos os riscos de ocorrer novo conflito de proporção mundial, envolvendo potências militares. O Conselho de Segurança simbolizava a solução de compromisso encontrada pelos Estados vitoriosos da Segunda Guerra para se exercer uma gestão condominial dos assuntos de segurança internacional dali por diante. "Não havia, na Carta da ONU, a expectativa de que a contribuição do Conselho de Segurança para [a manutenção de] a ordem fosse a de regular as aventuras externas de seus membros permanentes" - comenta Ian Hurd. "Sem a proteção do veto, [os 5 donos do veto] nunca teriam concordado com a existência da ONU (...). O compromisso primordial do Conselho não era o de proteger os pequenos Estados, mas o de evitar a guerra entre as grandes potências. Nesse quesito, ele tem-se saído bastante bem". ${ }^{6}$

Outra interpretação sobre a questão da adequação entre as metas inicialmente estipuladas e a capacidade da ONU de cumpri-las, foi fornecida por Hedley Bull. $\mathrm{O}$ autor percebe, em primeiro lugar, a difícil convivência entre os ideais da justiça e da ordem nos limites de uma comunidade internacional de Estados. A ordem é então compreendida como a perpetuação do sistema vestefaliano de Estados em que estamos inseridos. A manutenção da ordem constitui a tarefa a ser desempenhada pelas potências que, por diversos meios (o recurso à força entre eles), promoveriam a continuidade no status quo. Por sua vez, as demandas por mudança, geralmente acobertadas pelo mote da "justiça", costumam vir de Estados fracos, ou das organizaçōes da sociedade civil. O que Bull percebe é que a ONU, organização erigida para "dar cabo à era de flagelo e preservar as geraçôes vindouras do martírio da guerra", teria sido concebida para funcionar como um mecanismo central de replicação de valores dos Estados hegemônicos. Após examinar o primeiro capítulo da Carta da ONU, Bull defende a posição de que, no momento de fundação da organização, não se pretendeu dar conta de ideais como a "justiça" ou a "eqüidade" em nível global, mas, sim, de manter a ordem do pós-guerra.

4 ROBERTS, A. \& KINGSBURY, B. United Nations, Divided World. Oxford: Oxford University Press, 2003, p. 18.

5 Cf. N. Carlos, "A ONU não cumpre seu $1^{\circ}$ mandamento", Folha de S. Paulo, 17.7.2006.

6 HURD I. Too Legit To Quit, <http://www.foreignaffairs.org>, acesso em 2.1.2007.

7 BULL, H. The Anarchical Society. New York: Columbia University Press, 1977. 
Se analisamos a questão pelo prisma dos propósitos primários "nãodeclarados" da Liga e das Nações Unidas, identificamos outro quesito em que a última instituição angariou mais legitimidade do que a primeira. Isto porque, como adverte Inis Claude, há considerável evidência, hoje, de que o objetivo fundamental da criação tanto da Liga quanto da ONU era induzir os EUA a um comprometimento claro e inequívoco com a manutenção da ordem mundial, dedicando o seu poderio militar e econômico à supressão de agressões entre Estados. ${ }^{8}$ Como se sabe, embora Wilson tenha sido o grande responsável pela concepção da Liga das Nações, o país que ele presidia nunca chegou a ingressar no quadro de membros da citada organização, em função de contingências da política doméstica americana.

\section{Representatividade}

A ONU contou, desde a origem, com a presença dos EUA em seu corpo de membros. O desenho institucional se beneficiava do aprendizado com a experiência histórica, e, também por isso, a ONU tornou-se mais bem-sucedida, no quesito de representação geográfica, do que a Liga das Nações. Dois fatores parecem fundamentais para explicar a trajetória. O primeiro deles foi a criação de um órgão - a Assembléia Geral - concebido para abrigar todos os Estados reconhecidos como tais pela comunidade internacional. Por meio do princípio da estrita igualdade jurídica, a todos os Estados membros da organização é prevista a prerrogativa da soberania territorial, sem restrição. Essa condição de igualdade perante os pares implicava o reconhecimento do princípio da não-ingerência em assuntos domésticos de outros Estados, além da aplicação do sistema de "um Estado, um voto" nas questôes debatidas no âmbito da Assembléia Geral. Essa talvez tenha sido a grande novidade institucional representada pelo advento da Organização de São Francisco. O segundo elemento decisivo para a sobrevivência e o incremento da representação onusiana no mundo parece ser a composição do seu Conselho de Segurança - o órgão diretamente responsável pela manutenção da paz e da segurança internacionais. Em vez de restringir a sua composição a europeus (nos moldes da Liga pós-1933 e, antes ainda, da Santa Aliança, de 1815-25), esse novo Conselho conseguiu abranger, no sistema de representação permanente, América, Europa e Ásia, sem prescindir da presença de África e Oceania, em bases não-permanentes. Para mais, a composição (membership) da ONU balizou-se pela Declaração de Moscou (1943), a qual previa uma organização internacional de caráter geral, quase-universal, que abrangesse as nações "amantes da paz" que no mundo houvesse.

A ONU foi fundada por 51 Estados-membros, em 24 de outubro de 1945. Uma década depois, já tinha atingido a marca dos 76 membros. O salto mais

8 CLAUDE JR., I. Swords into Plowshares. New York: Random House, 1971: 79. 
impressionante, porém, deu-se nas duas décadas seguintes: como saldo do processo de descolonização afro-asiática (que a própria organização ajudou a catalisar), as Naçōes Unidas viriam a contar com 144 membros no ano de 1975 - quase o dobro de participantes da organização em 1955. A expansão prosseguiu, a despeito das pressões (típicas da Guerra Fria) pela não-admissão de certos membros, e, aos cinqüenta anos de idade, em 1995, a ONU continha 185 membros no seu quadro. Hoje, decorridas seis décadas desde a sua fundação, a Organização das Nações Unidas pode reclamar para si o estatuto de organização com abrangência (quase) universal, totalizando 192 membros $^{9}$ - um número quase quatro vezes maior do que o de fundadores, em 1945. Outra informação importante - que transcende o critério quantitativo - é que nunca um membro da ONU se retirou permanentemente da instituição. O caso solitário de saída temporária de um Estadomembro deu-se com a Indonésia, que, após anunciar a retirada da organização em 20 de janeiro de 1965 - "naquele momento e sob aquelas circunstâncias" -, regressou ao corpo de membros em 28 de setembro de 1966.

Nagendra Singh percebeu, para além dos avanços institucionais e do aumento vertiginoso do número de membros da ONU, uma tentativa, no texto da Carta de São Francisco, de purgar-se o etnocentrismo que marcou a existência da Liga. Haja vista que o preâmbulo do Pacto da Liga das Naçóes demandava "respeito escrupuloso a todos os tratados naqueles negócios que envolvessem os povos organizados". Pergunta-se: quais eram, então, os povos desorganizados? Que povos seriam esses com os quais se fazia perdoável desrespeitar tratados e obrigações constituídas? O etnocentrismo é igualmente perceptível no texto do Estatuto da Corte Internacional Permanente de Justiça - datado do início dos anos 1920 -, no trecho em que se faz menção aos "princípios gerais do direito internacional, reconhecidos pelas nações civilizadas". A interpretação possível é: somente as nações que consagram determinadas normas do direito internacional devem ser consideradas "civilizadas". É o que está sugerido. Em contraste, a Carta da ONU contém provisões que mitigam esse traço, destacando-se as idéias de "descolonização dos povos" e de "independência política com integridade territorial dos Estados-membros". Uma reminiscência do antigo sistema revela-se, porém, na instituição do Conselho de Tutela, o herdeiro do instituto do mandato, muito comum na prática colonialista da Liga. Essas mudanças nos textos legais e na prática política das Nações Unidas vêm da necessidade de ampliar a concepção de "comunidade internacional" no pós-Segunda Guerra, a fim de se lograr êxito na contemplação de mais Estados e de mais regiōes do planeta.

\section{Autonomização}

Quanto mais representativa uma entidade for, tanto mais difícil de ela se "descolar" das vontades daqueles membros que, em última análise, patrocinam

9 Após a admissão da República de Montenegro, em 28.7.2006. 
a sua existência material (os seus membros mais influentes, por assim dizer). $\mathrm{O}$ caso dos EUA segue emblemático. É o país que, além de ser o maior financiador da organização, ${ }^{10}$ ainda abriga em seu território os principais órgãos (Assembléia Geral, Conselho de Segurança, Secretariado etc.). Historicamente, as Nações Unidas demonstraram dificuldade em, a um só tempo, representar os interesses dos EUA, e autonomizar-se (quando considerado necessário) em relação a eles. Jennifer Welsh sugere que os EUA costumam julgar a legitimidade do Conselho de Segurança da ONU conforme a sua capacidade de fazer avançar uma concepção estadunidense daquilo que mais efetivamente representa a paz e a segurança internacionais. "Quando a concepção pode ser conciliada com a posição da maior parte dos membros do Conselho de Segurança, como nos casos de Somália e Bálcãs, os objetivos da ONU podem ser aprofundados. Do contrário, há conseqüências nefastas para a ordem internacional e a legitimidade do Conselho". ${ }^{11}$

$\mathrm{O}$ movimento de lenta e gradual autonomização da ONU em relação aos EUA data do fim da década de 1950, tempo em que o quadro de membros da organização expandiu-se com a independência política dos chamados "satélites" soviéticos - ex-colônias européias situadas na África, na Ásia e no Oriente Próximo. Michael Dunne nota que, a partir de então, "os americanos ficaram desiludidos com a ONU, onde o bloco 'afro-asiático' parecia representar um Terceiro Mundo pouco confiável politicamente e muito demandante economicamente, e os latinoamericanos não mais eram dependentes [dos EUA]". Japão e Europa Ocidental, elementos-chave da "esfera de influência" americana, passaram a discordar dos Estados Unidos em questôes pontuais, no âmbito da ONU. Em 1971, a República Popular de China ingressou na instituição, assumindo o lugar da representação de Formosa (Taiwan) no Conselho de Segurança. Crescentemente, como descreveu Daniel Moynihan, a ONU se tornava "um lugar perigoso para os americanos". ${ }^{12}$

Assim sendo, por décadas a fio, os EUA viraram as costas para a instituição - que eles não mais conseguiam controlar -, até que, com o fim da Guerra Fria, ensaiassem um retorno triunfante. O episódio da Guerra do Golfo (1990-1991) e o chamado a uma "nova ordem mundial" pareceram simbolizar, por um instante, o efetivo retorno dos EUA à ONU e, mais importante, a convergência de princípios entre o governo americano e o Secretariado onusiano. As suspeitas de que a ONU vigoraria, no pós-Guerra Fria, como plataforma de uma única potência hegemônica se dissiparam rapidamente, em face de dois eventos específicos: a intervenção da OTAN em Kosovo (1999) e, especialmente, a invasão militar do Iraque (2002-2003). Em nenhum dos dois casos, os diplomatas americanos

10 Em números correntes, os EUA arcam com $22 \%$ do total das despesas previstas pelo orçamento ordinário da ONU.

11 WELSH, J., "Authorizing Humanitarian Intervention” in PRICE, R. \& ZACHER, M. (org.), The United Nations and Global Security, Palgrave Macmillan, 2004, p. 188-9.

12 Apud GROOM, A. J. R. "The United States and the United Nations: Some Revolting European Thoughts", Journal of International Relations and Development, 6, 2003, p. 128. 
foram capazes de dobrar a ONU aos seus propósitos - embora tenha havido insistentes tentativas nessa direção. Em ambos os casos, houve larga manifestação da opinião pública internacional, com correspondente repercussão nos meios de imprensa. ${ }^{13}$

A julgar por esses dois vetores (o aumento da abrangência geográfica da organização e a perda relacional de poder das potências que a constituíram - os EUA, em especial), a tendência é de passagem - cadenciada - de um arranjo institucional oligárquico para uma disposição um pouco mais plural de poder. A tendência se faz acompanhar pelo reforço do princípio (ou da mera prática) do multilateralismo, em detrimento de açôes unilaterais (extralegais) dos membros que detêm o poder de veto no Conselho de Segurança. A tendência é diagnosticada com base no aumento dos custos políticos (junto à opinião pública, sobretudo) que uma eventual ação no sentido oposto daquele preconizado pela ONU pode acarretar (a julgar, principalmente, pelo episódio envolvendo a invasão do Iraque de 2003). ${ }^{14}$ A redução do número de usos do veto, no período pós-Guerra Fria, e os debates acalorados sobre a expansão da representação no Conselho de Segurança também servem como demonstrativos dessa trajetória provável.

\section{Exercício de coerção}

À turbulência dos anos 1990, sobrevieram oportunidades para a revisão de algumas questóes e a realização de certos debates nunca antes enfrentados no seio da Organização das Nações Unidas. Um deles, o que mais nos importa discutir neste tópico, remete à relação entre a autoridade política e o exercício de coerção por parte da ONU. Um primeiro ponto de importância para o debate é rever o papel da ONU vis-à-vis o dos Estados no que toca ao legítimo uso da força. Porque, se um dos elementos que autorizou, historicamente, a existência de Estados foi a sua faculdade de promover a ordem nas comunidades políticas (por intermédio da violência organizada), é fundamental ter-se em mente que o Estado moderno contou, desde os primeiros momentos, com exércitos - braços armados capazes de "fabricar" essa ordem. Esse monopólio do recurso legítimo à coerção é inclusive uma das principais fundações da Modernidade - um dos fatores que faz possível a noção de Estado moderno.

Por outro lado, a ONU não é, nem nunca foi, dotada de exércitos. Não é um "superestado", nem está apta, legal ou politicamente, a exercer o "monopólio da coerção legítima”. As açōes da ONU no campo da segurança internacional dão-se sempre por delegação dos Estados - nomeadamente, os cinco detentores do veto no Conselho de Segurança. O mais relevante, no momento atual, é que

13 Cf. DUNNE, M., "The United States, the United Nations and Iraq: 'multilateralism of a kind', International Affairs, 79, 2003, p. 257-77.

14 Relembrar os protestos realizados em várias cidades do mundo, em 15.2.2003, contra a invasão do Iraque, pela coalizão anglo-americana, sem o assentimento da ONU. 
esses Estados não parecem nem um pouco inclinados a empoderar a ONU para o exercício eficiente da coerção. Exemplo óbvio do que se alega é a inoperante Comissão de Estado-Maior, uma das inovações trazidas pela Carta da ONU, concebida para investir a instituição de São Francisco de um mínimo de capacidade para ação militar nas contingências, nos termos do capítulo VII. Além do quê, o dispositivo do artigo 43, que prevê para os Estados-membros a tarefa de disponibilizar forças para o rápido manejo do Conselho de Segurança, nunca foi efetivado, e permanece tão ineficaz hoje quanto durante a Guerra Fria.

Apesar disso, no segmento da segurança internacional, fica mais inteligível a concepção que temos externado - qual seja, de que poder e autoridade são fenômenos diferentes em essência. Isso porque, a despeito de todas as dificuldades enfrentadas pela ONU para fazer cumprir as suas determinações (ou seja, no que concerne à dimensão do "enforcement", do poder efetivo), ainda assim parece sustentável a tese de que, sob vários aspectos, a organização teve um incremento da autoridade política no plano internacional ao longo de sua existência - e, mais notoriamente, após o fim da Guerra Fria. Brian Urquhart percebe, por exemplo, que o capítulo VII da Carta da ONU é muito mais livremente invocado no pós-Guerra Fria do que antes. ${ }^{15}$ A tendência leva, dentre outros, a uma disputa acirrada pela reforma do Conselho de Segurança, a fim de que este possa expandirse e contemplar novos países e novas regiōes do globo. Por trás dessa disputa, existe o reconhecimento tácito à autoridade de um fórum que, noutros tempos, esteve engessado, incapacitado de desempenhar um papel, em face do confronto bipolar da Guerra Fria. A luta por uma vaga permanente no Conselho reflete, se nada mais, a crença na relevância do debate político encenado naquele fórum; e a expectativa de que as principais deliberações da política internacional do futuro passarão por aquela via institucional. Gareth Evans assinala ainda que, dada a imprecisão do texto da Carta da ONU e do direito internacional sobre o que seriam as proverbiais "ameaças à paz e à segurança internacionais", elas se tornam, na prática, aquilo que o Conselho de Segurança determina que sejam. ${ }^{16}$

Em vez de uma aferição da autoridade política da ONU pelo critério do exercício eficiente da coerção, sugere-se observar o uso simbólico que se tem feito da insígnia da instituição nas operações de paz pelo mundo (com o ocaso da Guerra Fria, sobretudo). Fomerand nota como, à ausência do poder efetivo do Secretariado para implementar certas investidas armadas, tem-se firmado uma prática de "subcontratação de capacetes azuis" por parte de potências com capacidade e disposição de agir. Isto quer dizer que a bandeira da ONU tem sido empregada, algumas vezes, para o propósito da legitimação das ações empreendidas por determinados Estados. Se não fossem encampadas pelas

15 URQUHART, B. "The UN and International Security After the Cold War" in BENEDICT \& KINGSBURY, op. cit., p. 86. Notar que, entre os anos de 1990 e 2002, 93\% das resoluçóes invocando o capítulo VII da Carta da ONU foram aprovadas ( 247 das 267 ocasiōes).

16 Cf. EVANS, G. "When is it Right to Fight?", Survival, 46, 2004, p. 59-82. 
Nações Unidas, dificilmente as tais campanhas disporiam de autorização política no plano internacional. Embora não exatamente consistente com o "espírito" da Carta de São Francisco, essa tendência revela o juízo, da parte dos tomadores de decisão dos Estados, de que o simbolismo do endosso onusiano gera maior permeabilidade normativa nos agentes sujeitos à sua ação. ${ }^{17}$

A capacidade de adaptação institucional da ONU no campo da segurança internacional é bem demonstrada pela evolução do que se convencionou chamar de "capítulo VI e meio" da Carta de São Francisco - para usar a expressão do exsecretário-geral Dag Hammarskjöld. Em face das dificuldades enfrentadas para exercer a coerção (não raramente impostas pelos próprios Estados-membros), a ONU desenvolveu um mecanismo de envio de operações de manutenção da paz a focos internacionais de tensão, o qual se robusteceu no correr dos anos. Desde 1948 - quando forças de manutenção da paz foram enviadas ao Oriente Médio, por ocasião da guerra da independência de Israel -, 60 operações do gênero foram organizadas - 47 das quais, no período pós-1988. ${ }^{18}$ O aumento vertiginoso de demanda por operações de manutenção da paz [peacekeeeping] da ONU nos anos após a Guerra Fria fez-se seguir pela diversificação e sofisticação das "operações de paz" da organização. Não tardou para que um departamento dedicado ao gerenciamento do peacekeeping onusiano fosse criado, além da providencial desvinculação entre os orçamentos regular e de operações de manutenção da paz da organização - que passaram, então, a ser contabilizados separadamente.

Originalmente restrita à diplomacia e aos "bons ofícios" do secretário-geral (o chamado peacemaking), a performance do Secretariado da ONU no campo da segurança internacional passou a englobar, além das já referidas "operações de manutenção da paz", a modalidade mais sofisticada da "construção da paz" (peace-building) e a assistência eleitoral. A operação de construção da paz remete "aos esforços para dar assistência a países e regiōes em transição da guerra para a paz, incluindo-se as atividades e os programas de suporte e fortalecimento dessas transições". ${ }^{19}$ Tais operaçõos chegam a envolver o envio de forças militares para a manutenção da paz, a repatriação e a reintegração de refugiados, a desmobilização e a reintegração de soldados etc. Trata-se, ao cabo, da tentativa de se estabelecer um novo Estado, com viabilidade técnico-administrativa e legitimidade sociopolítica. Interinamente, durante o processo de peace-building, a ONU assume as funções administrativas e de polícia do próprio Estado. Outro campo em que a ONU tem atuado é na assistência à realização de eleições em países marcados por algum tipo de instabilidade política. Desde 1989, quando supervisionou a eleição que levou à independência da Namíbia, a ONU foi requisitada para executar funções assemelhadas pelos governos de outros doze países. ${ }^{20}$

17 Cf. FOMERAND, J. "Recent UN Textbooks: Suggestions from an Old-Fashioned Practitioner", Global Governance, 8, 2002.

18 Dados referentes a dezembro de 2005.

19 Basic Facts About the UN. NY, 2004, p. 78-9.

20 Dados relativos a 2004. 
Cabe notar como difere, em relação à eficiência, a performance da ONU nas operações militares que o Secretariado pode gerenciar (destaque para o peacekeeping) e naquelas que ele não pode comandar. A dimensão do "fazer cumprir" extrapola a capacidade onusiana, uma vez que lhe faltam exércitos e o mandato para recorrer legitimamente à força, por conta própria. Daí a constatação do terceiro secretáriogeral da ONU, U Thant, para quem "não é surpreendente que a organização seja culpada por falhar na resolução de problemas que já haviam sido considerados insolúveis por governos". ${ }^{21}$

A questão que sumariza o debate desta seção, então, é a seguinte: para afirmar a sua autoridade política, a ONU deve exercer eficientemente a coerção? Se analisarmos os fundamentos da autoridade de Estados e da ONU, tenderemos à negativa - ou seja, tenderemos a corroborar a idéia de que a dimensão da autoridade política da ONU não se relaciona diretamente com a capacidade de coerção da organização. Haja vista a hesitação dos próprios Estados-membros em equipar com recursos militares e de inteligência o Secretariado das Nações Unidas - deixando clara a indisposição de estender à ONU a prerrogativa do exercício da coerção. Nem sequer se menciona a independência militar da entidade nos debates políticos atuais. Adicionalmente, resta a alegação de que a força simbólica do secretário-geral provém exatamente de sua imparcialidade, derivada da falta de engajamento prévio com qualquer parte em contenda. A fim de manter a credibilidade como "terceira parte", a ONU - dissociada identitariamente dos Estados que a integram - abstémse, via de regra, de tomar partido em conflitos. ${ }^{22} \mathrm{Na}$ palavra do ex-secretáriogeral assistente da ONU, Giandomenico Picco, "transformar a instituição do Secretariado [da ONU] em uma pálida imitação de Estado na gestão do uso da força pode ser uma tática suicida". ${ }^{23}$ A esse respeito, John Ruggie, por exemplo, opina taxativamente: "a ONU e o mundo estarão em melhores condições futuras se baixar o perfil militar da organização, e se ela não se intrometer no cálculo estratégico dos Estados". ${ }^{24}$ Afinal, a ONU não é (nem está municiada para fazer as vezes de) um Estado - por acaciano que pareça reafirmá-lo.

\section{Produção normativa}

Embora não tenha sido imaginado como um corpo legiferante, o sistema ONU desenvolveu, nas últimas seis décadas, regulação internacional sobre um amplo espectro de temas e situações. Mais do que isso, a ONU foi capaz de gerar normas e padrões que têm balizado, de forma direta ou indireta, o convívio

\footnotetext{
21 Apud WEISS, T. et al., The United Nations and Changing World Politics. Boulder: Westview Press, 2001, p. 106.

22 DE CUÉLLAR, J. P. Cyril Foster Lecture. Oxford, 13.5.1986.

23 PICCO, G, “The U.N. and the Use of Force", Foreign Affairs, 73, 1994, p. 15.

24 RUGGIE, J. G. The United Nations and the Collective Use of Force: Whither? Or Whether?. New York: UN Association of the USA, 1996: 1.
} 
entre os Estados e demais atores internacionais, transformando-se, para a quase totalidade dos Estados-nação, na fonte institucional mais preeminente do direito internacional contemporâneo. ${ }^{25}$

De uma perspectiva constitucionalista, a Carta da ONU corresponderia ao texto fundamental das relaçôes internacionais. É a Carta que fornece o corpo de princípios que vem sendo seguidos pelos Estados (com maior ou menor fidelidade) ao longo das últimas seis décadas. Para termos um bom índice de quão autoritativa é a Carta de São Francisco como fonte de direito e da prática política internacional, conveniente é observar a influência dos valores por ela preconizados nas relações internacionais da segunda metade do século XX. Singh analisa a matéria, e percebe a emergência de uma série de princípios de direito internacional no pós-guerra, dentre os quais: o princípio do não-uso da força nas relações internacionais e ilegalidade de "direito de conquista" como modo de aquisição territorial [artigo 20 $(3,4)]$; os princípios de independência e igualdade soberana entre os Estados, e o conceito de descolonização; o princípio da igualdade de direitos e de autodeterminação dos povos [artigos $1^{\circ}(2)$ e 55]; o princípio da não-intervenção em assuntos domésticos [artigo 2० (7)]; o princípio da não-discriminação [artigos 10 (3); 13, alínea "b"; 55, alínea "c"]; o princípio da cooperação internacional [artigo 13, alínea "b"]; o princípio da boa vizinhança e das relações amigáveis [artigos $1^{\circ}$ (2); 55 e 74]; os princípios relativos aos direitos humanos [artigos 1० (3); 13 (1); 55, alínea "c" e 62 (2)]; o princípio do registro obrigatório de tratados [artigo $102(1)]{ }^{26}$

Embora alguns dos princípios citados antecedam a própria Organização das Nações Unidas, é somente com a elaboração da Carta que eles ganham uma formulação mais precisa e um estatuto legal mais sólido. Torna-se redundante, pois, afirmar a importância histórica que noções como as de "descolonização" ou de "autodeterminação dos povos" desempenharam na dinâmica política do nosso tempo. Contribuições importantes da ONU ao campo principiológico das relações internacionais contemporâneas também vêm da Convenção sobre a Prevenção e a Punição do Crime de Genocídio, de 1948, que define, tipifica e prevê punição para práticas genocidas; dos protocolos e convençôes universais sobre direitos humanos (a Declaração Universal dos Direitos Humanos, de 1948, sendo a mais célebre delas); das conferências organizadas pelas Nações Unidas (destaque para as conferências sobre temas globais, realizadas a partir dos anos 1970), das convenções de Viena sobre relaçôes diplomáticas e consulares (1961 e 1963) e sobre leis dos tratados (1969), etc.

Do ângulo que concede à ONU a condição de fonte prescritiva, incluemse as diretivas, escritas ou não, que, pelo fato de emanarem das Nações Unidas, revestem-se de caráter vinculante, à luz do direito internacional. Leis que vinculam

25 Cf. JOYNER, C. (org.). The United Nations and International Law. Cambridge: Cambridge University Press, 1998; SINGH N., "The UN and the Development of International Law" in Roberts and Kingsbury, op. cit.

26 SINGH, op. cit., p. 389-92. 
são aquelas que impõem direitos e obrigações aos seus sujeitos, podendo ou não ser respaldadas por sançōes punitivas. No seio da instituição, a principal fonte de prescriçōes é o Conselho de Segurança, o único dos órgãos da ONU capaz de produzir resoluções vinculantes sobre os Estados-membros - e de recorrer à força para fazê-las cumprir. ${ }^{27}$ Outra prolífica fonte de prescrições é a Assembléia Geral. Embora as suas resoluçōes não tenham caráter vinculante perante o direito internacional, na prática, tais declaraçōes têm freqüentemente servido de estágio preliminar para a confecção de tratados multilaterais, eventualmente promulgados sob os auspícios da ONU. Outra serventia das "recomendações" da Assembléia Geral refere-se à cristalização de normas (sobretudo, no campo dos direitos humanos) que, depois de ecoarem na ONU, são incorporadas como leis pelos ordenamentos jurídicos nacionais. Ademais, conquanto a Assembléia Geral não se pretenda um "poder legislativo mundial", as suas resoluções não-vinculantes podem servir de instrumento concreto para dirimir controvérsias referentes à interpretação de normas internacionais, bem como para inspirar certas práticas governamentais, considerado o peso político que um documento aprovado em um fórum de pretensão universalista como a Assembléia pode assegurar.

$\mathrm{O}$ direito administrativo internacional trata das normas referentes a poderes, procedimentos e processos de revisão judicial. No contexto da corrente discussão, relaciona-se, principalmente, às agências administrativas vinculadas ao sistema ONU. Desse ponto de vista, as Naçōes Unidas constituem rica fonte normativa, dada a sua centralidade nas relações internacionais contemporâneas e a abrangência das atividades que a entidade desempenha (o que acarreta a existência de uma gama de agências administrativas sob a sua supervisão). Assim, a ONU tem contribuído, de forma consistente, para a produção de legislação administrativa internacional. Destacam-se, nesse processo gerativo, os aportes do Secretariado (a atuação do secretário-geral, em particular) e das agências especializadas da organização.

No que toca ao Secretariado e ao secretário-geral, compete notar como uma rede normativa foi-se tecendo no decorrer dos 60 anos de existência da ONU. Trata-se de um tipo de legislação que, dado o inédito grau de complexidade do empreendimento a que se dedica o Secretariado onusiano - hoje -, é elaborado à medida que a vida política internacional se desenrola. Em outras palavras, a emergência de novos atores, fenômenos e processos na cena internacional demanda novas formas de gestão das relações internacionais, além de, obviamente, constante renovação da legislação administrativa internacional. Sob a liderança do secretário-geral, o Secretariado tem-se lançado em missões tais como a promoção do entendimento pela via da "diplomacia silenciosa", os bons ofícios e a reconciliação de partes em contenda; criando, assim, precedentes políticos e normativos na gestão internacional de crises. Outra área em que se observa

27 Entre 1945 e 1996, o Conselho de Segurança adotou cerca de mil resoluções, das quais 400 eram vinculantes. 
com suficiente clareza a força normativa onusiana é no relativo às operações de manutenção da paz. A ampla margem de discricionariedade em que opera o Secretariado permite o desenvolvimento de uma doutrina legal de peacekeeping, bem como de procedimentos e práticas, que acabam sendo transformados em legislação internacional pela via do direito costumeiro.

Resta ainda que, consistentemente com o artigo 102 da Carta da ONU, "todo tratado e todo acordo internacional, concluído por qualquer membro das Nações Unidas depois da entrada em vigor da Carta, deverá (...) ser registrado e publicado pelo Secretariado". Dispositivo ao qual se faz a seguinte ressalva: "nenhuma parte em qualquer tratado ou acordo internacional que não tenha sido registrado de conformidade com as disposiçōes do parágrafo 1 deste artigo [acima enunciado] poderá invocar tal tratado ou acordo perante qualquer órgão das Nações Unidas". De sorte que, nos últimos 60 anos, praticamente toda a produção de legislação internacional escrita foi submetida ao secretário-geral, registrada e arquivada na ONU. A condição imposta pelo artigo 102 denota, se nada mais, o papel onusiano de garantir a publicidade e conferir o timbre da legitimidade aos documentos jurídicos envolvendo pessoas de Direito Internacional Público (principalmente, os Estados).

A autoridade da ONU como fonte de legislação internacional fica ainda mais evidente quando se trata de salientar o papel jogado por suas agências especializadas no estabelecimento de parâmetros e normas de referência na administração de vários campos de atividade humana. Os exemplos são abundantes nesse sentido. Citam-se alguns: a FAO (Food and Agriculture Organization) tem-se incumbido, desde 1945, de fixar os índices nutricionais adequados para o bem-estar das populações; a Organização Internacional da Aviação Civil, parte do sistema ONU desde 1947, é responsável pela harmonização de toda a legislação internacional concernente a serviço meteorológico, controle de tráfego e de comunicações aéreas, radiodifusão, operações de busca e resgate, etc; a Organização Internacional do Trabalho, criada em 1919, exerce considerável influência sobre os padróes trabalhistas internacionais; a União Internacional de Telecomunicações, fundada em 1865 (e integrada ao sistema ONU em 1947), é encarregada da regulação internacional sobre todas as formas de comunicação via rádio, telégrafo, telefone e radiocomunicadores espaciais, além de gerir as freqüências de rádio de todos os mais de 180 países a ela filiados. E, assim, sucessivamente, cada agência especializada do sistema ONU desempenha funções de regulamentação de uma determinada área temática das relaçôes internacionais, gerando, à medida que exerce as suas atribuições, arcabouço normativo.

\section{Papel do secretário-geral}

O secretário-geral é a referência política mais alta das Nações Unidas. Dispõe de prerrogativas legais que nenhum chefe de Estado no mundo estaria 
apto a exercitar. Uma delas, enunciada no artigo 99 da Carta da ONU, dispóe que "o secretário-geral poderá trazer à atenção do Conselho de Segurança qualquer matéria que, na sua opinião, possa ameaçar a paz, e requeira o exercício do julgamento político independente do Conselho de Segurança” (grifo nosso). $\mathrm{Na}$ comissão que conduziu os trabalhos preparatórios até a fundação da ONU, já se afirmava, à luz do malogro da experiência prévia com a Liga das Nações, que "[o secretário-geral], mais que qualquer outra pessoa, deverá responder pela ONU como um todo. Aos olhos do mundo, ele deverá encarnar os princípios e ideais da Carta à qual esta Organização [ONU] dá efeito". Não surpreende, portanto, que o artigo $7^{\circ}$ da Carta estabeleça o Secretariado - chefiado pelo secretário-geral - como o principal órgão onusiano. Essa elevação do estatuto jurídico (e político) do secretário-geral da ONU, em relação à Liga das Nações, não se deu por acaso, admite Javier Pérez de Cuéllar:

Esse não foi um desenvolvimento fortuito. Ao contrário, foi ditado pela experiência da Liga das Naçôes. O Pacto e a prática da Liga eram baseados em uma concepção puramente administrativa do posto do secretário-geral. Os eventos calamitosos que guiaram à Segunda Guerra revelaram que isso havia sido um equívoco. Um perigoso vazio existia (...). Sir Eric Drummond, o primeiro secretário-geral da Liga das Nações, teria dito que, se o artigo 99 da Carta estivesse ao seu dispor, a influência da Liga sobre os eventos que se sucederam poderia ter sido diferente. ${ }^{28}$

O acréscimo de autoridade à instituição do secretário-geral da ONU é mais perceptível, porém, na prática do que na legislação. Desde Trygve Lie, todos os secretários-gerais têm afirmado a independência do seu ofício - alguns mais vigorosamente do que outros - e, para tanto, (re)interpretado as provisōes da Carta de São Francisco sempre em favor da expansão do papel do secretário-geral na condução das crises políticas internacionais. Lie ajudou a instaurar o "direito" (não previsto pela Carta) de o secretário-geral oferecer opiniōes não-solicitadas ao Conselho de Segurança. ${ }^{29}$ Dag Hammarskjöld observou, em famoso discurso, que o artigo 99 permitia ao secretário-geral ampla margem de discricionariedade para "engajar-se em atividade diplomática informal no que concerne aos assuntos que ameacem a paz e a segurança internacionais". Inventou a chamada "fórmula de Pequim", uma alusão à prática - tornada corriqueira - de total distanciamento do secretário-geral em relação às partes em contenda. U Thant foi um dos responsáveis pelo desenvolvimento da técnica da "diplomacia silenciosa" do secretário-geral - a qual foi considerada uma alternativa à invocação (muito mais dramática) do artigo $99 .{ }^{30}$ Especificamente sobre a importância da "diplomacia

28 DE CUÉLLAR, J. P. "The Role of the UN Secretary-General” in ROBERTS \& KINGSBURY, op. cit., p. $128-9$.

29 Eventualmente transformado em regra de procedimento provisional.

30 Cf. JOHNSTONE, I. "The Role of the UN Secretary-General: The Power of Persuasion Based on Law". Global Governance, 9, 2003, p. 441-458. 
silenciosa", afirmou o ex-secretário-geral da ONU Javier Pérez de Cuéllar que "ninguém nunca saberá quantos conflitos terão sido evitados ou limitados através dos contatos estabelecidos na famosa 'mansão de vidro', que pode tornar-se ligeiramente opaca quando necessário". ${ }^{31}$

Kofi Annan atuou, logo que da sua eleição, para ampliar o escopo de atuação política dos secretários-gerais. Em fevereiro de 1998, negociou diretamente com Saddam Hussein um memorando de entendimento que autorizava o retorno dos inspetores de armas ao Iraque. Ao agir de ofício, sem um mandato formal do Conselho de Segurança, o secretário-geral acreditava escudar-se em um "direito adquirido", constituído, na prática, pela atividade diplomática de seus antecessores no cargo. Percebe-se a discricionariedade do secretário-geral Annan na sua promoção ostensiva de regimes democráticos pelo mundo. A promoção da democracia não é um dos objetivos explícitos da Carta, embora possa derivar, em uma hermenêutica ampla e permissiva, da doutrina onusiana de direitos humanos e do próprio princípio de autodeterminação dos povos - dois dos ingredientes constitucionais da ordem internacional construída no pós-Segunda Guerra. Annan ainda tem sido responsabilizado pela maior atenção destinada a temas africanos na pauta política da organização - o que se atribui à sua nacionalidade ganense.

Ian Johnstone percebe, no entanto, que as distintas interpretações concedidas ao artigo 99 pelos secretários-gerais da ONU não se tornam autoritativas pelo simples fato de emanarem de secretários-gerais. O secretário-geral é, para o autor, apenas um membro influente da comunidade de intérpretes associados às Nações Unidas que, através de práticas discursivas, contribui para a afirmação de uma determinada hermenêutica legal. Ele afirma que

Essas [interpretações ao artigo 99 da Carta da ONU] não foram afirmações unilaterais de autoridade ou exercícios abstratos de reforma da ONU, mas instâncias de inovação que foram levantadas, discutidas e aceitas no contexto de disputas específicas que se davam no seio da instituição. Nos moldes da evolução do direito costumeiro, essas criativas interpretaçóes do papel do secretário-geral foram transformadas em norma compatível com a Carta. ${ }^{32}$

\section{Emergência dos temas globais}

No atual estágio das relaçōes internacionais, a emergência de temas globais, que abrangem potencialmente toda a superfície do planeta, passou a demandar um novo tipo de gestão pública - que os tradicionais Estados territoriais têm

31 Apud FRANCK, T. \& NOLTE, G. "The Good Offices Function of the UN Secretary-General” in ROBERTS \& KINGSBURY, op. cit., p. 144.

32 JOHNSTONE, op. cit., p. 444. 
sido incapazes de realizar a contento. São questões que requerem uma abordagem transfronteiriça, uma vez que as suas causas e os seus efeitos já não mais se adscrevem a um ou outro Estado, região ou conjunto de Estados. Os assim chamados "temas globais" constituem realidade com a qual poucos agentes internacionais se credenciam a lidar. A ONU, graças a sua vocação universalista e representatividade em escala planetária, é talvez a instituição que mais tem avançado - apesar dos não raros reveses - a gestão pública internacional em campos como os direitos humanos e o meio ambiente. Daí provém parte substancial da autoridade adquirida no pós-Guerra Fria, em tempo de globalização da economia e da política internacionais. Outra noção que vem ao encontro do novo papel político onusiano - no mundo sob o impacto da globalização - é a de "bens comuns globais" (global commons). Está-se a referir aos novos espaços que, em função, sobretudo, de avanços tecnológicos, passam a transcender a jurisdição territorial dos Estados. Configuram novas áreas, comumente descritas como "espaços extraterritoriais", crescentemente sujeitas à regulação do direito internacional. $\mathrm{O}$ alto mar, a atmosfera, as terras glaciais da Antártica, o espaço sideral e o campo eletromagnético da Terra são considerados espaços extraterritoriais - todos eles tutelados legalmente por documentos com o timbre da ONU.

Nossa avaliação é de que a dinâmica política do mundo contemporâneo ajuda no alargamento da constituency da ONU. O que implica reconhecer que a possível evolução das relaçôes internacionais para um cenário de governança global e a emergência de fontes de "autoridade privada" (acompanhada pelo relativo enfraquecimento da autoridade política do Estado territorial moderno), contribuem para que a ONU venha projetar internacionalmente os valores e as regras que emergem de um processo de produção normativa cujo centro é ela própria. Perceber ademais que, na análise da autoridade da ONU na política internacional, o que está em jogo é menos a capacidade operacional da Organização das Nações Unidas de intervir efetivamente em todas as questōes e campos mencionados anteriormente (direitos humanos, proteção ambiental, gestão conjunta de global commons), e mais a autoridade política de que a organização se encontra investida para agir, para exercer as funções de governança global.

Assim, se há uma entidade autorizada a conceber padrōes de comportamento, parâmetros, metas, regras, estratégias de longo alcance etc. sobre "temas globais" no mundo de hoje, essa é a Organização das Nações Unidas. ${ }^{33}$ Pesados os fatores que importam, a ONU desponta como a instituição politicamente credenciada para tentar suprir as lacunas deixadas pela atuação dos Estados nessas diversas áreas das relaçôes internacionais. É, sobretudo, nesse aspecto particular que se aplica o velho dito segundo o qual, se não existisse, a ONU teria de ser inventada.

33 A fala do secretário-geral Annan é ilustrativa desse entendimento: "Terrorism is a global menace. It calls for a united, global response. To defeat it, all nations must take counsel together, and act in unison. That is why we have the United Nations". UN Press Release, SG, 18.9.2001. 


\section{Notas finais (ou "o saldo contábil")}

Ameaças à $\mathrm{ONU}$ e a sua autoridade política poderiam ser listadas às dezenas. Elas sempre estiveram presentes, e continuam, ainda hoje, a rondar a instituição. Falta de autonomia financeira, déficit democrático e de accountability, ineficiência administrativa, influência de interesses espúrios, distorção do mandato original da organização, duplos padrões, corrupção, anacronismo estrutural, campanhas discursivas de difamação etc., embora configurem desafios nada desprezíveis à integridade da Organização das Nações Unidas, não foram capazes de fazer ruir a instituição. Tampouco de solapar a sua autoridade política.

Como já identificado no decorrer do artigo, as fundações dessa autoridade onusiana residem, mais destacadamente, em quatro características (que comumente lhe são associadas): (i) a pretensão de universalidade, (i) a pretensão de imparcialidade, (iii) a vantagem cognitiva comparativa em certas áreas temáticas (expertise) e (iv) a formatação institucional inclusiva.

Da sua pretensão de universalidade deriva, por exemplo, a defesa da bandeira dos direitos humanos. A advocacia e a promoção dos direitos humanos, dos direitos humanitários e dos direitos dos refugiados, por parte da ONU, alimentam a autoridade política da instituição, não somente aos olhos dos chefes de Estado e de governo do mundo, senão também dos indivíduos. Essa é, muito provavelmente, a forma mais efetiva de responsividade (responsiveness) que a ONU pode executar em escala mundial, na sua relação direta (não necessariamente mediada por Estados) com os indivíduos.

A sua pretensão de imparcialidade fica bem ilustrada no aumento sem precedente, havido nos anos 1990, da requisição das intervenções da ONU em zonas de conflito por todo o globo. Não fosse percebida como uma espécie de agente demiúrgico, politicamente acima das partes em contenda, dificilmente a instituição seria tão solicitada após a Guerra Fria. E é dessa alegada imparcialidade que a organização retira o "salvo-conduto" para ingressar em conflitos como terceira parte politicamente autorizada.

Da vantagem cognitiva do pessoal onusiano em alguns assuntos ditos "técnicos" - aliada à imparcialidade e à universalidade da organização - advém a autorização política para a emissão de pareceres sobre diversas áreas temáticas, desde as políticas de ciência e tecnologia de um Estado até os sistemas de detenção carcerária. Donde a legitimidade com que são recebidos os relatórios de oficiais da ONU. Isso ajuda a explicar, adicionalmente, a força (e a relativa insuspeição) das estatísticas tornadas disponíveis pela ONU ou alguma de suas agências especializadas.

Por fim, é da formatação institucional arrojada - e, até certo ponto, vanguardista - que a ONU (entendida como o "sistema ONU") extrai a reivindicação de ser a organização internacional mais bem equipada para dirimir as principais querelas das relações internacionais contemporâneas. Somente em um ambiente capaz de 
abrigar, sob o mesmo teto, Estados e atores não-estatais, faz-se possível alguma gestão dos assuntos internacionais contemporâneas. As Conferências Sociais da ONU, realizadas ao longo da década de 1990, são exemplares dessa capacidade de promoção do diálogo e do entendimento em diversos níveis das Nações Unidas.

Diferentemente do Estado moderno, que contou, desde a sua gênese institucional, com exércitos fiéis ao governante, capazes de gerar a ordem doméstica e promover a guerra com outros Estados; e coletores de impostos, incumbidos de taxar os cidadãos e recolher os tributos que financiariam o aparelho de governo; a ONU nunca dispôs desses recursos. Nunca teve braços armados próprios, tampouco os meios de autofinanciamento. Das perspectivas militar e orçamentária, a ação onusiana sempre dependeu diretamente da concessão dos seus Estados-membros. Uma entidade com as características da ONU, desprovida de "dentes" operacionais, não deve aspirar ao papel de enforcer internacional, nem deve se orientar pelo ditame da "eficácia" ou ser avaliada pelo critério do "exercício eficiente do poder". A dimensão conceitual a que a Organização das Nações Unidas pertence é, por excelência, a da autoridade política. É a dose de autoridade política de que está investida a ONU o que garante, possivelmente, a sua continuidade, a sua sobrevivência institucional. E, nesse sentido específico, poder-se-á afirmar que o saldo onusiano, nos primeiros sessenta anos de vida, é positivo.

Recebido em 5 de janeiro de 2007 Aprovado em 16 de abril de 2007

\section{Resumo}

Buscaremos analisar o estatuto da autoridade política da ONU, recorrendo a referenciais quantitativos e qualitativos, por meio da proposição de uma relação positiva entre a "autoridade onusiana" e um conjunto de variáveis. Após avaliação dos resultados, pretendese gerar discussão a respeito dos limites institucionais e da natureza da autoridade da ONU na política internacional contemporânea, corroborando-se a hipótese de que o quantum de autoridade de que está investida a ONU é crescente no curso das últimas seis décadas.

\section{Abstract}

In this article we attempt to evaluate the current status of UN's political authority, by way of both qualitative and quantitative methods, as we posit the existence of a positive relation between UN's authority and a set of variables. After assessing data, we intend to generate debate on the limits and the ontological nature of the United Nations organization in contemporary international politics, as we support the hypothesis that the degree of political authority the UN is vested with is increasing in the course of the last six decades.

Palavras-chave: ONU, autoridade, política internacional, organizações internacionais. Keywords: UN, political authority, international politics, international organizations. 